\title{
Negotiating the Nuclear and Humanitarian Crisis on the Korean Peninsula: A Simulation and Teaching Guide
}

Courtney J. Fung, University of Hong Kong

ABSTRACT This article describes a simulation scenario based on of-the-minute thinking about the Korean Peninsula crisis. The scenario highlights the tradeoffs and difficulties in addressing the nuclear and humanitarian crisis, tasking students to negotiate to reach consensus on track I and track II levels. Students are negotiators, gaining experience and exposure to key international relations and political science concepts through active learning. An optional media-teams and press-conference component also is discussed. The scenario, grading rubric, and supplemental materials are included to give instructors a resource that is easily modified across groups varying in size, ability, and composition.

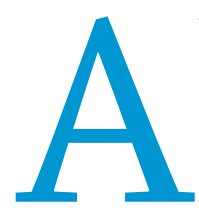

lthough there is a wide literature on simulation scenarios, there is no up-to-date simulation listed for one of the most important foreign-policy crises facing the world today: the Korean Peninsula issues. ${ }^{1}$ This article describes a simulation scenario that reflects of-the-minute thinking about the Korean Peninsula crisis and highlights the tradeoffs and difficulties in addressing the nuclear and humanitarian crisis. New research challenges conventional assumptions about the strength of the Democratic People's Republic of Korea (DPRK)-China relationship, as well as the downplaying of non-traditional security issues such as mass human rights abuse, disease, migration, and state collapse as problems on the Peninsula. ${ }^{2}$

This negotiation simulation lasts at least two weeks, plus a debriefing session. Assignments are scaffolded in for preparation, including a team-background paper, a two-minute opening speech for the negotiations, and debriefing mini-assignments. This simulation is useful for an introductory international relations class and, given its versatile themes, it also can be used in a more advanced course on East Asian regional relations, international organizations, and security studies. The simulation is straightforward to run and does not require too much teaching preparation or additional class materials.

\section{BENEFITS OF A SIMULATION}

Students are decision-making negotiators addressing the crisis with overlapping, conflicting interests to secure-and limited capabilities

Courtney J. Fung is assistant professor of international relations in the Department of Politics and Public Administration at the University of Hong Kong (ORCID ID ooooooo1-6498-6oo6). She can be reached at cjfung@hku.hk. to execute-their goals. The simulation is grounded in real-world context and emulates a professional setting. Students are required to make a connection between doctrinal learning and the real world and the social context around them. Through this learning by doing, students perform beyond basic recall of theory as they engage in higher-order thinking to resolve complex, ill-defined problems. ${ }^{3}$

The simulation highlights the different dominant theoretical perspectives of international relations, including debates about whether zero-sum bargaining outcomes are inevitable (i.e., a nuclear-missile attack); how states' domestic interests affect international cooperation (i.e., does Japan's focus on addressing abductee issues mean defection from a united front against DPRK nuclear expansion?); and norms around appropriate action or the social construction of "security" (i.e., should there be a prioritization of nuclear-security issues over massive humanitarian concerns?). The simulation also emphasizes core international relations concepts including the security dilemma, (mis) perceptions, and historical memory. This scenario has many benefits for large introductory international relations, East Asian politics, and security studies courses. Many of the teams have built-in, two-level negotiating tensions that could be exploited by Pyongyang to gain concessions. The tension between finding an international-level outcome (between negotiating teams) that might be acceptable for individual teams and their imagined publics highlights problems of the two-level game. Students also will grapple with more esoteric concepts such as "reputation" and "status" as they assess why certain teams are still invited to the talks. In my experience as an instructor, questions are raised about Russia's participation in the simulation even though it is 
no longer as significant a player in Korean Peninsula politics. The simulation then invites discussions about how states form reputation and status.

\section{THE SIMULATION SCENARIO}

The scenario incorporates traditional and non-traditional security issues in the context of massive economic and social concerns. Drawing from news headlines, the scenario emphasizes that the DPRK continues to test its ballistic-missile systems while pursuing the miniaturization of its nascent nuclear-weapons stockpile. The scenario also notes the DPRK production of highly enriched highlight the difficulty in executing a successful "stag hunt" against the DPRK, wherein Pyongyang can exploit nation-states' competing interests as part of its diplomatic strategy. Similarly, Switzerland, Sweden, the IAEA, and the track II negotiators face constraints about operating within DPRK-approved boundaries. Their different corporate identities shape their response to the scenario and their willingness to cooperate with one another. For example, the Eugene Bell Foundation focuses on diagnosing and treating tuberculosis, which may make it a reluctant player in addressing the writ of the Committee for Human Rights in North Korea.

\section{The tension between finding an international-level outcome (between negotiating teams) that might be acceptable for individual teams and their imagined publics highlights problems of the two-level game. Students also will grapple with more esoteric concepts such as "reputation" and "status" as they assess why certain teams are still invited to the talks.}

uranium, which has the sole purpose of making nuclear weapons. Along with these latest nuclear- and missile-related developments, there are other non-traditional security pressures. The 2014 United Nations Commission of Inquiry on Human Rights in the DPRK found unparalleled crimes against humanity, and interest continues to grow about the Commission's recommendations for action. The scenario notes that the DPRK faced an unseasonably long and bitter winter, which meant concerns about food, health, and migration, coupled with reports of a new strand of bird flu carried by North Koreans crossing the border.

The negotiation's players are loosely based on a modified Six-Party Talks format with the six nation-states: the DPRK, United States, Republic of Korea (ROK), Japan, China, and Russia operating on a track I level. Along with these states, other track I negotiators include Switzerland and Sweden, given their long-standing diplomatic representation in Pyongyang and their presence as Neutral Nations Supervisory Commission members monitoring the demilitarized zone. Given its expertise in nuclear affairs, the International Atomic Energy Association (IAEA) also is a track I negotiator.

The track II negotiators include the small number of declared foreign non-governmental organizations and educational institutions that are present in the DPRK. Leaders from the Pyongyang University of Science and Technology, Red Cross Society of the DPRK, United Nations Country Team in the DPRK, and Swiss Agency for Development and Cooperation are invited to offer expertise and guidance on addressing the social, developmental, and security issues listed in the simulation. I also added the Committee for Human Rights in North Korea because of renewed interest in the human rights conditions in the DPRK.

The scenario sets up a classic two-level game. For example, the nation-state players have varying levels of interest in the success of the talks, given their competing interests and capabilities. The United States, the ROK, and Japan all have interests in securing their foreign nationals in the DPRK. China has particular concerns about managing the border, given the population of ethnic Koreans, tuberculosis infection rates in the DPRK, and potential for a costly state collapse. Russia is keen to maximize its technical expertise and diplomatic prestige. The competing interests
The objective for the negotiations simulation is for both tracks to produce their own joint statements, which must complement one another. All track I and track II players must sign their joint statements. There is no correct outcome for the simulation or the content of the joint statements.

\section{SETUP FOR THE SIMULATION}

Before the onset of negotiations, the instructor provides a brief recap of the history, security, and political situation on the Korean Peninsula, including prior successes and failed attempts at negotiations. The instructor then issues the one-page scenario (see appendix $\mathrm{A}$ in the online supplemental materials) and reminds students that negotiations do not begin until their assigned kickoff date. The simulation itself is run over two weeks, incorporating all lecture and recitation meetings. When negotiations are complete, the subsequent lecture period should be reserved for debriefing and discussion.

The instructor divides students into groups representing the negotiators at the track I and track II levels. The ideal size for each group is three to four students. Larger groups can be accommodated; however, this ideal number permits active participation from all members, reduces the opportunity for "free-riders," and facilitates groups focusing on a cohesive list of negotiating points.

Negotiating teams then turn to their preparatory tasks of researching and writing their team-background papers. These papers address the team's historical background vis-à-vis the issues contained in the scenario, the team's capabilities and interests, and their core goals for the negotiations. They present their strategy for negotiations-for example, which other teams are negotiating partners and which issues are priorities. Students are encouraged to draw insights from their team's past practices in prior rounds of negotiations and from their broader foreign-policy behavior, in which tactics included the use of highlevel summitry among select players; the incentives of economic, food, and medical aid; or the use of sanctions as punishments. Negotiation processes also should recognize key strategic realities such as China's de facto control over DPRK sanctions enforcement and the military disparities between the DPRK and the ROK. Students should consider "natural" negotiating partners 
(e.g., Switzerland and Sweden could form a negotiating pair given their decades of cooperation as military observers) and be encouraged to leverage relationships across the different negotiating tracks. For example, the Swiss Agency for Development and Cooperation and Switzerland would have an innate opportunity for coordinated policy. Other than the team, only the instructor will see the background paper; therefore, students can write frankly and directly. This group project familiarizes students with their teammates and prepares them for the negotiations by gaining knowledge and expertise about their assigned team. Students appoint their individual roles within teams, divided by either national focus or function. For example, a four-person Japan team may decide to define their team by specialists in Japan-US and ROK-Japan relations, abductee issues, and health-security issues. Clearly utilizing team members highlights the relevance of these issue areas for negotiations. Written and in-person feedback is provided by the instructor. Ideally, teams then have a week between receiving feedback and the beginning of negotiations so that negotiators can reformulate goals and strategies if needed.

Once the written and personal feedback is given on their policy-background papers, the negotiations commence in a single room during lecture time; this simulates the actual proximity of negotiating chambers. Negotiations begin with teams preparing to deliver a two-minute opening speech. The speeches serve the important function of distilling the key points from each team's policy papers, prompting negotiators to think about what their most important message is for the forthcoming negotiations. Moreover, these speeches are the first time that other teams can learn about their counterpoints' interests, capabilities, and priorities. If there are time constraints, teams will be chosen at random to deliver their speeches; other speeches can be uploaded to the class

\section{DEBRIEFING AND ASSESSMENT}

Debriefing is crucial for students to process their negotiation activities and articulate their connections to course learning goals. The debriefing is key from a pedagogical viewpoint because it reinforces what students have learned through traditional learning and assessment modes. It also provides additional opportunities for students to make new connections between their negotiations experience and their knowledge from lectures, recitations, and readings.

When the class reconvenes to debrief, the instructor is again a facilitator, eliciting student discussion on topics that include the relevance of readings to the negotiations, surprising outcomes, and how the simulation relates to issues in the news. For example, if the scenario is used in the context of an East Asian regional studies class, then the instructor's questions during the debriefing can focus students on themes covered in the course. To what extent did the negotiations reflect the problems of historical memory? Given the scenario, how could the negotiations be better addressed to the Korean Peninsula crisis? What are the impediments to a more robust response to the Korean Peninsula crisis? How does the negotiations experience reflect real-world events? For a class on foreign-policy analysis, students could be prompted to reflect on whether their negotiations experience presents a model for dealing with crises and the implications for decision making at the international level.

Various straightforward assessment aids can be used to facilitate the debriefing. A simple handout at the end of each lecture and recitation sessions asks students to answer four questions: What did you do during this class? What were your goals for this session? Did you achieve your goals? (If not, why not?) Do you need to change your goals for the next session? Using these completed handouts gives students an opportunity to capture changes in their thinking and approach over the two-week period.

\section{The speeches serve the important function of distilling the key points from each team's policy papers, prompting negotiators to think about what their most important message is for the forthcoming negotiations. Moreover, these speeches are the first time that other teams can learn about their counterpoints' interests, capabilities, and priorities.}

online platform for subsequent reading. In lecture settings, students often set up working groups or caucuses, trying to figure out broader aspects of cooperation. In smaller recitation settings, students hammer out details of their agreements with other negotiators. Negotiators also may use Facebook groups, WhatsApp chat groups, and other means to reach negotiation success within the set time period.

The instructor announces his or her veto over proposals that clearly reject reality (e.g., the United States abruptly disbands all alliance commitments with Japan and the ROK). The instructor must not use the veto for proposals that appear surprising or extreme as long as the negotiating points do not violate each group's capabilities or interests. Once the negotiations begin, the instructor's role shifts to meeting with student teams, prompting them to conceptualize their goals more clearly, asking about acceptable parameters, and discussing negotiating tactics. In this way, the instructor becomes a facilitator for the negotiations. Instructors of larger classes might benefit from having more teaching assistants to observe negotiators and foster self-critical conversation.
Alternately, students can submit a short critical self-reflection paper about their individual experiences in the team and in the negotiations. This paper can be used to understand the inner workings of the group and relieve free-rider concerns that are inevitable in group-based assignments. Both documents assist the instructor in assessing learning by providing evidence of how students process the effects of competing interests and constraints of limited capabilities as negotiators. The matrix included in online appendix B is a grading scale for negotiators' performance during the simulation.

\section{EXTENSION}

A press-corps component can be added to the simulation to further model the two-level conditions present in the simulation. Students in these teams are reporters, not negotiators, and they play a key role in the success of the negotiations. Press teams, composed of three or four students, are assigned to each nation-state present in the simulation to cover breaking news and leaks and to write editorials based on the negotiations progress. The press 
corps serves an invaluable function as another source of information and analysis, while also reinforcing domestic pressures on the negotiating groups through critical or supportive reporting. Each national player should have a press team (e.g., ITAR TASS, CNN, Korean Central News Agency, Asahi Shimbun, The People's Daily, Chosun Ilbo, Dagens Nyheter, or 20 Minuten) and, if class size permits, a different array of political views represented by the press outlets (e.g., Washington Post, Wall Street Journal, and New York Times for the United States and Daily NK and Korean Central News Agency for the DPRK). Press teams write team-background papers in which they note the objectives, political persuasion, and their media outlet's existing critical coverage of the Korean Peninsula crisis. Press teams also choose their individual roles: either functional specialties (e.g., health editor) or national specialties (e.g., Japan news editor). The press corps meets their assignments by producing at least two articles regarding the negotiations, which are published on the class online platform. An additional lecture session can be reserved for a media conference to critically assess the process of the negotiations and the content of the joint statements.

\section{CONCLUSION}

This simulation enriches the instruction of international affairs as students take on real-world roles negotiating a resolution for the Korean Peninsula crisis. The simulation allows students to negotiate an outcome for a crisis with no "good" solution, reflecting the realities of cooperation under constraints. The process of negotiations gives students a more intimate understanding of why massive humanitarian crises continue and the failure to address apparently vital security threats. The simulation captures many core international relations concepts and is adaptable to other courses.

\section{SUPPLEMENTARY MATERIAL}

To view supplementary material for this article, please visit https://doi.org/10.1017/S1049096518001026

\section{ACKNOWLEDGMENTS}

I thank James E. Platte, Wilfred Wan, and the anonymous reviewers for their insights and improvements to my earlier drafts, and Joseph C. W. Chan and Injoo Sohn for their support and encouragement of my teaching activities. This research was supported by a 2016 University of Hong Kong Early Career Teaching Award.

\section{NOTES}

1. Simulation scenarios often use fictional states (e.g., Newmann and Twigg 2000; Stodden 2012; Young 2006) or other regional crises (e.g., Chasek 2005 used a terrorist attack in Singapore; Kempston and Thomas 2014 used a South China Seas simulation scenario; and Siegel and Young 2009 used the Middle East).

2. For example, see Mastro (2017) about Sino-DPRK relations and Bae and Natsios (2018), who consider the effects of disease, refugee flows, and state collapse on the Korean Peninsula.

3. There is an extensive literature on the benefits of simulations in political science and international relations classrooms. Newmann and Twigg (2000) discussed the benefits of this active learning, especially for students who may not respond as well to conventional approaches. Kempston and Thomas (2014) emphasized the benefits of metacognitive skills for students' ability to become self-directed learners. Young (2006), Kanner (2007), Stodden (2012) and Hunzeker and Harkness (2014) noted that simulations promote students' ability to apply theory to practice. Shellman and Turan (2006) and Powner and Allendoerfer (2008) noted the benefits of simulations for leading to improved assessment performances.

\section{REFERENCES}

Bae, Joonbum, and Andrew Natsios. 2018. "Preventing a Post-Collapse Crisis in North Korea." Foreign Affairs, January 25. Available at www.foreignaffairs.com/ articles/north-korea/2018-01-25/preventing-post-collapse-crisis-north-korea.

Chasek, Pamela S. 2005. "Power Politics, Diplomacy and Role Playing: Simulating the UN Security Council's Response to Terrorism." International Studies Perspectives 6 (1): 1-19.

Hunzeker, Michael A., and Kristen A. Harkness. 2014. "The Strategy Project: Teaching Strategic Thinking through Crisis Simulation.” PS: Political Science $\mathcal{E}$ Politics 47 (2): 513-17.

Kanner, Michael D. 2007. "War and Peace: Simulating Security Decision Making in the Classroom." PS: Political Science \& Politics 40 (4): 795-80o.

Kempston, Tanya, and Nicholas Thomas. 2014. "The Drama of International Relations: A South China Sea Simulation.” International Studies Perspectives 15 (4): 459-76.

Mastro, Oriana Skylar. 2017. “Why China Won't Rescue North Korea.” Foreign Affairs 97 (1): 58-66.

Newmann, William W., and Judyth L. Twigg. 200o. "Active Engagement of the Intro IR Student: A Simulation Approach." PS: Political Science \& Politics 33 (4): $835-42$

Powner, Leanne C., and Michelle G. Allendoerfer. 2008. "Evaluating Hypotheses about Active Learning." International Studies Perspectives 9 (1): 75-89.

Shellman, Stephen M., and Kürşad Turan. 2006. "Do Simulations Enhance Student Learning? An Empirical Evaluation of an IR Simulation.” Journal of Political Science Education 2 (1): 19-32.

Siegel, David A., and Joseph K. Young. 2009. "Simulating Terrorism: Credible Commitment, Costly Signaling, and Strategic Behavior." PS: Political Science $\mathcal{E}$ Politics 42 (4): 765-71.

Stodden, William P. 2012. "Simulating Humanitarian Aid Decision Making in International Relations Classrooms." PS: Political Science \& Politics 45 (4): 765-71.

Young, Joseph K. 2006. "Simulating Two-Level Negotiations.” International Studies Perspectives 7 (1): 77-82. 